\title{
JUVENTUDE E AVENTURA EM MIMNERMO
}

Teodoro Rennó Assunção

UFMG

Resumo: Este artigo pretende investigar; a partir da polaridade juventude / velhice, a descrição do amor como experiência-chave da juventude na obra de Mimnermo. Serão ressaltadas nesta experiência as dimensóes do prazer e da gratuidade lo elemento de aventura). Será estudada ainda a inconsciência, característica da juventude, como condição para o prazer.

Palavans-chave: Mimnermo, juventude, amor, gratuidade.

Desconsiderados os fragmentos de caráter mítico-narrativo, toda a primeira parte da obra de Mimnermo, isto é, os fragmentos de 1 a 7 na edição de $M$. L. West, parece girar em torno do tema da oposição entre juventude e velhice. Mimnermo inaugura em relação a Homero uma nostalgia intensa da juventude, cujo suposto é a supervalorização desta, assim como uma espécie de horror ante a velhice vindoura (ou experimentada), cujo suposto complementar é sua completa desvalorização. Sabemos pela figura de Nestor que em Homero o decréscimo da força vital na velhice é compensado pela sabedoria que é fruto da experiência; e que inversamente, como atesta 0 Antíloco do canto 23 da IIfada, 0 excesso de energia viril é acompanhado na juventude pela ausência de bom-senso e prudência. Não encontramos este equillbrio em Mimnermo. No entanto, este poeta conservará de Homero o modo básico de representação da juventude e da velhice. Pois como bem observou W. Schadewaldt (Schadewaldt, 1933, p.291), juventude e velhice formam em Homero os dois polos irredutiveis de uma oposição de que está excluída qualquer transição e onde falta a percepção da necessidade da sucessão e da conseqüente totalidade regulada pelo devir. Para Homero, e de algum modo para Mimnermo, juventude e velhice não são processos temporais mas entidades definidas de uma vez por todas por certas características. Por isto ele diz que a velhice "chega aos homens" ou a vê de maneira tal que ela "tem", "acossa" ou "agarra" o homem. Já Mimnermo dirá que "dolorosa sobrevém velhice" ou que "penosa e disforme ela está sobreposta sobre a cabeça".

Observada esta polaridade entificada, bem ao gosto do pensamento arcaico, que organiza em Mimnermo o contraste juventude / velhice, seria preciso dizer que ele se demora mais na descrição desta última. Apesar de os fragmentos serem breves, é visivel, por pequena que seja a diferença, que 0 acento mais forte está posto na velhice. Mas seria ingenuidade pensar que a juventude é menos considerada. Ele apenas usa técnicas contrastivas de descrição que reforçam a oposição de fundo. Assim à minúcia enumerativa empregada na descrição da velhice ele oporá uma técnica de flashes breves e fulgurantes para a juventude. E enfim no plano vocabular, como notou R. Schmiel (Schmiel, 1972, p.288), a velhice está 
caracterizada por verbos marcando o "arrastamento", enquanto a juventude é definida por advérbios que insistem na brevidade.

Detenhamo-nos então nestes breves flashes. 0 primeiro deles, formado por um verso apenas, é paradoxalmente a única descrição direta do amor em um poeta cujo verso, no dizer de Propércio, "vale mais do que o de Homero nas coisas do amor" (1.9.9). Logo após a pergunta retórica que abre a elegia 1(W) "Que vida, que prazer sem dourada Afrodite?", ele exclama: "esteja morto, quando estas coisas não mais me preocupem:" e vem então o terceiro verso definindo "estas coisas": "secreto amor, suaves dons e o leito".

Dois comentadores apenas se detiveram com atenção no sentido do terceiro verso do fragmento 1 de Mimnermo: C. M. Dawson e A. W. H. Adkins. Ambos coincidentemente comentavam as relações entre a linguagem de Mimnermo e a de Homero. C. M. Dawson (Dawson, 1966, p. 48 e 49) lembra que na seqüência do célebre símile da geração das folhas no discurso de Glauco na lliada $(6,146-149)$ é contada a estória de Belerofonte, acusado falsamente pela rainha Antéia, mulher de Proitus, de haver tentado se unir a ela kryptadiei philoteti, isto é, "em secreto amor". Como ele bem aponta, kryptadiei tem neste contexto homérico o sentido negativo de "furtivo", "ilicito". Em Mimnermo o sentido é outro: kryptadíei significaria "não-público", "privado", marcando apenas a esfera adequada à manifestação do amor. A Hera do canto 14 (333-6) da llíada teme a vergonha de ser vista pelos outros deuses fazendo amor com Zeus em espaço aberto. Já Hannah Arendt observa, comentando a diferença entre o domínios páblico e 0 privado, que, sob pena de morrer ou se apagar, o amor não pode "suportar a iluminação da presença do outro sobre a cena pública" (Arendt, 1983, p.90). C. M. Dawson lembra também que "a expressão philotes kal euné é familiar aos leitores de Homero: afeição ou amor que atinge a culminação na cama" (Dawson, 1966, ps.28,49). Mas por que quebrar a fórmula inserindo méllikha dôra, "suaves dons?" Como a expressão é significativa demais para estar meramente preenchendo espaço, ele se sente tentado a ver neste verso "a mais breve das histórias de amor: kryptadie philotes, um plácido beijo ou abraço, meílikha dôra, induçōes concretas posteriores e finalmente euné, a consumação" (Dawson, 1966, p. 49).

Mas se interpretarmos meilikha dôra como os presentes que quebram a resistência do ser amado, abrindo a via à consumação do ato, é estranho que em seguida, comparados com as flores da juventude, estas sejam ditas "colhiveis por" ou "atrativas para" (harpaléa) "homens e mulheres". "Homens", andrásin e não "rapazes", paisín, como seria de se esperar se se tratasse do objeto masculino do amor, do amado (eromenos) tal como o verso nono deste mesmo poema atesta. Pois o equivalente possivel para mulheres, enquanto receptor destes presentes, isto é, objeto da corte amorosa, termo passivo desta relação, só poderia ser em poesia paîs, plural paides, "garotos", "rapazes" como indica K. J. Dover (Dover, 1978, p.16) (na prosa sobretudo ocorre o termo de mesma raiz paidiké com o sentido singular masculino de "jovem amado") e não anér, o macho guerreiro adulto em plena posse de sua virilidade, mesmo se para a mentalidade arcaica considerado jovem em contraposição ao velho, isto é, ao homérico incapaz para a guerra ou em Mimnermo ao incapaz para 0 amor. Portanto meílikha dôra "suaves dons", não poderia ter aqui o sentido de "induções concretas posteriores" a um "plácido beijo ou abraço", como quer C. M. Dawson, nem poderíamos ter a seqüência cronologicamente evolutiva de uma estória de amor. Qual o sentido então de meílikha dôra? Se nos lembrarmos 
do começo do Hino homérico a Alrodite (1-3), onde esta deusa é primeiramente definida como "a que mais dá aos mortais os suaves dons e sempre sorri na face desejável", talvez possamos tal como A. W. H. Adkins sugerir o sentido de "prazeres concedidos à humanidade por Afrodite" (Adkins, 1985, p.100), isto é, "prazeres do sexo". A proximidade (Mimnermo 1W, 1) de "prazer", terpnon, e de "dourada Afrodite", khrysês Aphrodfites confirmaria o sentido, referindo os dons à deusa e imantando de presença divina toda a esfera erótica.

E se quisermos compreender melhor 0 ato divino do dom, temos de nos referir a llíada $(3,64-66)$, onde Páris, após pedir a Heitor que não o censure pelos "dons amáveis", dôr'eratá, da "dourada Afrodite", khrysês Aphrodítes (dons que são neste contexto os cabelos e a beleza), irá dizer que "não são desprezíveis os gloriosos dons dos deuses, quantos dons eles próprios dêem, e que ninguém voluntariamente (hekon) obteria". Não poderiam ser estes dons o resultado de um esforço humano consciente, obra calculável. Eles se mostram divinos justamente por não poderem ser escolhidos, possuindo por isto um quê de aleatório e de gratuito. Gratuidade aplicável também aos prazeres eróticos que, enquanto dons, não podem ser merecidos, escapando a qualquer possibilidade de cálculo. Trata-se pois não de presentes concretos ou de graça concedida por um ser humano, mas do dom maior do deus que concede a possibilidade do encontro de desejos. Esta "graça suplementar do destino", nos termos de Georg Simmel, não é humanamente decidivel. Por isto "no mais assegurado e glorioso evento deste domínio encontra-se alguma coisa que temos de aceitar humildemente" (Simmel, 1989, p.317). Seria demasiada ousadia conceber também assim o fenômeno do orgasmo?

De qualquer modo, se interpretarmos assim meílikha dôra, as três expressões que compõem o terceiro verso de Mimnermo 1W, isto é, "secreto amor, suaves dons e o leito", representam de modo discreto e diferenciado o mesmo fenômeno: 0 ato sexual, percebido porém em sua dimensão religiosa, uma vez que não há prazer sem Afrodite. E eles não mais entretêm entre si nenhuma relação temporal, sendo todos os três termos definidos como a culminação da juventude na imagem erótica das flores.

Não é de estranhar que em sua segunda ocorrência "flores da juventude", ánthesin hébes $(2 \mathrm{~W}, 3)$, seja complemento dativo de "nos regozijamos (com)", terpómetha. É o prazer erótico que organiza este campo semântico. Mas gozamos "por pouco tempo, parecidos às folhas que rapidamente crescem sob a ação dos raios do sol na multiflorida estação da primavera". Neste símile também, como ensina a lição de $\mathrm{H}$. Fränkel sobre o símile homérico, há mais de um ponto de comparação: a juventude é não só a multiflorida estação da primavera da vida como é semelhante em sua rapidez de manifestação às folhas que esta estação faz brotar. E elas brotam tão rápido quanto é curto o tempo do gozo com as "f!lores" do prazer.

Se a temporalidade, no modo da brevidade, é o ponto focal da comparação, o poeta introduz uma outra modalização deste prazer quando diz que "com flores da juventude nos regozijamos, pelos deuses não sabendo nem o mal nem o bem". Ao prazer portanto é associada a inconsciência. Mas o tom aqui não é crítico como na elegia de Semônides de Amorgos (6-9) que pode, no entanto, funcionar como um comentário: "Enquanto um dos mortais tenha a flor mui-amada da juventude, tendo o ânimo leviano, pensa muitas coisas irrealizáveis: pois nem previsão tem de envelhecer nem de morrer, nem, quando está sadio, tem a preocupação do esgotamento" Comentário possivel porque sugere, tal como em 
Mimnermo $2 \mathrm{~W}$, que somente o conhecimento do mal pode levar à valorização do que é bom. Pois, como observa $\mathrm{H}$. Fränkel, segundo "o princípio da polaridade, 0 bem por si mesmo não pode ser compreendido" (Fränkel, 1975, p.210). Diferentemente de Semônides, que preza o conhecimento, Mimnermo porém certamente diria que "o velho conhece demais o bem e o mal para ser feliz" (Fränkel, 1975, p. 210). A ignoråncia aparecendo portanto como condição de felicidade, tal como está expresso na máxima de Jéhu: "Heurese jeunesse, qui ne sait pas" (Schmiel, 1972, p. 287).

Robert Schmiel engenhosamente considera explicativa a oração que segue, chamando a atenção para o dé adversativo e para o perfeito parestékasi ao traduzir: "mas as negras Keres já estão postadas perto, uma com a pesarosa velhice, a outra com a morte" (Schmiel, 1972, p. 284). A idéia de que desde a juventude a morte e a velhice já estejam presentes permite nuançar em Mimnermo 0 corte abrupto entre juventude e velhice, deixando entrever a figura da unidade na percepção sutil de que assim como a velhice contém em si o passado da juventude, a juventude contém em si como futuro último a velhice e a morte. Mas considerar a seguir, como Schmiel o faz, que a velhice representa o mal e a morte o bem, ambos ignorados durante a juventude, nos parece equivocado, mesmo se é evidente a presença do desejo de morte em duas outras passagens do poeta (1W, $2 ; 2 W, 10)$. A contraposição não se dá entre velhice e morte entre si, mas entre ambas, que representariam $0 \mathrm{mal}$, e a juventude, que representaria 0 bem. 0 que falta à juventude, falta que lhe permite paradoxalmente a felicidade, é a projeção do haver de envelhecer e do haver de morrer. É a inexistência de uma adequada perspectiva do futuro que cria por sua vez um modo temporal de ser (e perceber) em que a dimensão do presente domina e o prazer não está manchado pelas preocupações. Este ser-presente é a-histórico também porque o fardo do passado é ainda pequeno e a presença dos eventos em curso consome mais do que a memória. A submersão na embriaguez do instante ofusca a temporalidade e a finitude. É como se o prazer intenso pudesse apagar o tempo. Não há porém aqui, como na moral heróica, a busca da transcendência numa glória que ultrapassa a morte, e sim a sugestão de uma mais completa imersão na imanência do instante, que nada garante senão a precária plenitude da experiência.

Resume: Cet essai a l'intention de commenter, à partir de la polarité jeunesse/vieilesse, la description de l'amour comme éxpérience-clé de la jeunesse dans l'oeuvre de Mimnerme. Dans cette éxpérience seront mises en relief les dimensions du plaisir et de la gratuité (l'élément de l'aventure). Sera étudiée encore l'inconscience, caractéristique de la jeunesse, comme condition du plaisir.

Mots-cle: Mimnerme, jeunesse, amour, gratuité. 
Bibliografia

ADKINS, A. W. H. Poetic craft in the early Greek elegists. Chicago: The University of Chicago Press, 1985.

ARENDT, H. Condition de I'homme moderne. Trad. G.Fradier. Paris: Calmann-Lévy, 1983.

DAWSON, C. M. Spoudaiogéloion: Random Thougts on Occasional Poems. Yale Classical Studies XIX, 1966.

DOVER,K. J. The greek homosexuality. London: Duckworth, 1978.

FRÄNKEL, H. Early Greek Poetry and Philosophy. Trad. M. Hadas e J.Willis. Oxford: Basil Blackwell, 1975.

SCHADEWALDT, W. Lebenszeit und Greisenalter im fruehen Griechentum. Antike 9, 1933.

SCHMIEL, R. Youth and age: Mimnermus 1 and 2. Rivista di Filologia di Istruzione Classica 102, 1972.

SIMMEL, G. L'aventure. In: Philosophie de la modernité. Trad. J. L. Vieillard-Baron. Paris: Payot, 1989. 